\title{
BEING WISE AND BEING FEMALE IN OLD TESTAMENT AND IN AFRICA ${ }^{1}$
}

Funlola Olojede

Old and New Testament

Stellenbosch University

\begin{abstract}
Woman Wisdom in the book of Proverbs is viewed as an enigmatic figure who performs multifaceted roles of a teacher, builder, and nourisher, among other things. Drawing on Proverbs 9:1-6, this paper looks at the depiction of Woman Wisdom as a hospitable woman who beckons to others to come and share of her bounty. The association of the seemingly affluent Woman Wisdom with hospitality calls to mind the image of the African woman who carries out her own hospitality and accommodativeness often in the midst of aggravating poverty. The paper therefore urges the wealthy to take a cue from Woman Wisdom and be more ready to share freely of their overflow and of their space as a way of alleviating poverty in Africa and upholding the dignity of all. It also calls on women and women groups to

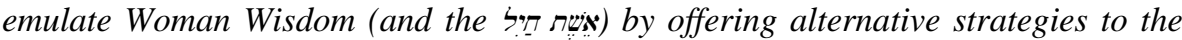
chronic poverty on the continent.
\end{abstract}

Key Words: Woman Wisdom, Poverty, Proverbs

\section{Images of Woman Wisdom in Proverbs (9:1-6)}

The term Woman Wisdom is often used to describe the personification of wisdom as a woman in Wisdom literature, especially in the unit of Proverbs 1-9 where personification is employed as a striking rhetorical device to attribute female imagery to wisdom. ${ }^{2}$ The personification of Woman Wisdom is found in several passages in the unit but this discussion will concentrate on Proverbs 9:1-6. While some scholars settle for an early or pre-exilic dating of Proverbs 1-9, other scholars favour a late or exilic/post-exilic dating (i.e. between the sixth and third century BCE). ${ }^{3}$ However, Hadley (1995:239) remarks that Proverbs 1-9 has defied all attempts at a precise dating but that majority of scholars are prone to place it in the fifth to fourth centuries BCE. ${ }^{4}$

1 This article was presented as a paper at the Workshop on Old Testament Wisdom Literature (Old Testament Wisdom, Human Dignity and the Poor) held on 21 and 22 September 2012 at the Faculty of Theology, Stellenbosch University.

Murphy (1990:133; 1995:222-233).

Although several scholars support a late dating of the introductory material (e.g. Camp 1985; Meinhold 1991; Clements 1992:24; Weeks 1994; Harris 1995:22; Sinnott 2005:6), some argue for late dating and regard the Book of Proverbs as belonging to the Persian period or the Hellenistic period (e.g. Perdue 1997 - early Persian period; and Waltke 2004 - Hellenistic period).

4 See Yoder (2001:15-38) on the challenges involved in the dating of Proverbs 1-9 whether it is based on external or internal (linguistic) evidence. Yoder herself settles for a sixth century to third century post-exilic dating (Yoder 2003:428; 2009:xxiii). For a thorough-going appraisal of the dating of the book of Proverbs, however, read Whybray (1995:10ff). 
Although the varied arguments on the origin of personified Wisdom remain inconclusive, recent scholarship tends to favour a post-exilic (sixth to third century BCE) dating for the final redaction of Proverbs 1-9. It has been established that Proverbs 1-9 is widely accepted as a unified composition and the work of a single author whether from a structural, formal, metaphorical/symbolic or mythical viewpoint.

It seems appropriate here to note the tendency by scholars, who situate the text of Proverbs 1-9 in the exilic/post-exilic era and interpret Woman Wisdom from a sociological viewpoint, to regard wisdom's origins and development as the response to Israel's situation after 587 BCE. For instance, Sinnott argues that the situation of exile made it necessary and acceptable to personify wisdom as a female figure who speaks for God. With the fall of Jerusalem, the loss of the Temple, the Davidic monarchy and the land, as well as the trauma of the exile, Israel's understanding of a God who acts, could not effectively address the crisis that ensued. ${ }^{5}$

Sociological approaches to the study of Woman Wisdom "perceive personified Wisdom as a product of social impulses within Israel that drew upon the lives of Israelite women for their imagery". ${ }^{6}$ A good example is Claudia Camp, who states her preference for understanding the meaning of female Wisdom within a socio-historical setting. ${ }^{7}$ Yoder also presents a socio-historical, specifically, a socio-economic reading of Proverbs 1-9 and 31:10-31 but Dell investigates both the social and theological context of the book of Proverbs and of Proverbs 1-9. ${ }^{8}$

Various other interpretations of Woman Wisdom in Proverbs 1-9 as a whole have identified her as a 'multifaceted' character that performs multifaceted roles, specifically, of a (peripatetic) teacher, a prophet or a builder but also with God as a nourisher. ${ }^{9}$ Sinnott sees her as a 'supple' and 'flexible' character whose personifications 'are coloured by their settings'. In Proverbs 9:1-6, Woman Wisdom sent out an invitation to her lavish banquet that would take place in the house, which she built. Woman Wisdom as a host or provider of food, is said to relate to the metaphor of the God who feeds his people - a common image of God in the Old Testament (Ps 104:15; Is 55:1-2). Therefore, Claassens affirms that, "there is a parallel between Wisdom's and God's provision of food". 10 Judith McKinlay has also considered Woman Wisdom as a host who sends out an invitation to guests. Her canonical reading of Proverbs 9:1-6 compares Wisdom to Sophia in Ben Sira 24 and to Jesus in John 4 (cf. John 7:37). Like Wisdom, Sophia issues an invitation to others to come, eat and drink, but Jesus invites the Samaritan woman to come and drink only. Remarkably, all three invitations are accompanied by an offer of life. ${ }^{11}$

Proverbs 9:1-6 is the shortest of the three Woman Wisdom poems (i.e. Prov 1:20-31; $8: 1-36$; 9) and it depicts a unique feature of Woman Wisdom - she owned a mansion, what Lang calls 'a patrician house' that was constructed on seven pillars. She then organised a

\footnotetext{
Sinnott $(2005: 53-87,171)$.
}

Sinnott (2005:13).

Schroer (1995) embraces a similar approach. Note, however, Yoder's (2001:9) claim that both Camp and Schroer have prioritized the literary expression of Woman Wisdom over the socio-historical context.

8 Camp (1985:17-18); Yoder (2001; 2009: xxii); Dell (2006; 2009). See Perdue (1997) for another interpretation of Proverbs 1-9 from both a theological and a social viewpoint.

See Baumann (1998:44ff); Claassens (2004:83-98); Sinnott (2005:171).

Sinnott (2005:175-176); Claassens (2004:90).

11 McKinlay (1996). A remarkable point by McKinlay is that while in Proverbs and Ben Sira the caller is female (i.e. Wisdom and Sophia), in John 4, the caller is male (Jesus). The author questions whether the texts reflect a gender shift in the thinking of the ancient authors, that is, from feminine to masculine. 
lavish banquet to which she invited guests. ${ }^{12}$ Although, this woman's discourse was clearly set in the public arena, as many commentators have noted, it is remarkable that Wisdom equally had her locus in the house as 9:1-2 indicates. In those two verses, Woman Wisdom's activities took place in that seven-pillared mansion, which she built.

Woman Wisdom has been compared with different female characters in the book of Proverbs such as Dame Folly or the Strange Woman of Proverbs 7:5-27; 9:13-18. In particular, several commentators have posited a correspondence between Woman Wisdom and the alphabetic acrostic poem of 31:10-31. ${ }^{13}$ For instance, Yoder claims that both Woman Wisdom and the אשׁׁת חַיל coalesce as one figure, that is, based on lexical and semantic parallels in the passages that describe them. ${ }^{14}$ Highlighting the wisdom dimension of the אשֶת חיזיל, Yoder notes that interpreters have characterised the vשֶׁת חַיל variously as an allegory of wisdom, an epitome of wisdom or a symbol of wisdom. However, she claims that a socio-economic reading of the Proverbs 31:10-31 reverses the trend to show Wisdom as and a composite image of real women ${ }^{15}$ in the Persian period who were exceptional, ${ }^{16}$ and that Wisdom also reflects the socio-economic realities of Persian-period women.

For her part, Masenya also sees a parallel between Woman Wisdom and the אשׁת חַירל Her reading of Proverbs 31:10-31 from an African perspective, analyses the image of woman in Proverbs as mother, wife and 'the other'. Taking a cue from Camp (1985:84), Masenya affirms that one of the roles of the wife in the Old Testament world is that of a household manager. She, however, adds that this role is not uniquely Israelite but a universal phenomenon. In Africa, specifically among the Northern Sotho of South Africa, women are viewed traditionally as household managers but not in a financial sense because, since the colonial era, most of these women have been disempowered financially and operate in the context of poverty. ${ }^{17}$ In spite of these limitations, many African women remain strong and hold their homes together.

Further in the discussion, we shall attempt a brief socio-economic reading of Woman Wisdom's portrayal in Proverbs 1-9 in relation to the $31: 10-31$. The assumption is that Woman Wisdom's invitation in the passage could be read as an invitation to the poor and the hungry especially in Africa.

\section{Poverty - Old Testament and Africa}

What is poverty? Perhaps the meaning of poverty is best captured in the words of a Kenyan man:

\footnotetext{
Compare Lang (1986:87, 93-95); Perdue (1994:79); Dell (2009a:239).

See Whybray (1995:102, 106); (Yoder 2001:93, 2); Dell (2006:86); Mansenya (2004).

14 Yoder (2001:12, 91-93; 2003:446; 2009:290). Brenner (1993:129) agrees that, "The language which describes the Worthy Woman echoes the language employed for describing the female Wisdom figure. The former is in fact Wisdom, the bountiful, the kingpin of family existence".

15 Yoder $(2001: 93,101)$.

16 It is pertinent to note here that Sinnott (2005:9) argues against the position that the Woman of Worth of 31:1031 is a concluding portrayal of personified Wisdom and is closely related to 1-9: "I argue that this poem is a portrayal of an earthly woman/wife who is humanly real but idealised... Woman Wisdom (1-9) and the Woman of Worth (31:10-31) respectively open and close the book of Proverbs, but do not merge or even converge as one figure". Nonetheless, Sinnott does not elaborate on the reasons for her stance neither do we find her suggestion persuasive.

17 Masenya (2004:90-91; 146-50).
} 
Don't ask me what poverty is because you have met it outside my house. Look at the house and count the number of holes. Look at the utensils and the clothes I am wearing. Look at everything and write what you see. What you see is poverty.

- Poor man, Kenya ${ }^{18}$

This poor man's trenchant description of poverty shows that poverty stares us in the face. Poverty is a common global phenomenon that is not restricted to a particular historical era, people, race or geographical location. It is a human reality that was also witnessed in the biblical world. It has been argued in some quarters that a definition of poverty is only possible relative to wealth because poverty is not an accidental or isolated phenomenon but is determined by the structures of the society, that is, it is connected to the society's social framework. In the biblical tradition, it could be seen as a human creation that is not only limited to the economic but also to the social and political orders. ${ }^{19}$

Boerma notes that the approach of the biblical tradition to poverty was not passive. Poverty is challenged in the Bible. In fact, all the major corpuses of the Old Testament reflect concerns for the poor and the needy and studies show that the sages also offer a variety of approaches to deal with poverty. ${ }^{20}$ While wisdom literature and the book of Proverbs in particular attribute poverty to individual choices and attitudes such as laziness, negligence or foolishness, the rich and the oppressor are also held accountable for the condition of the poor in the society. Being poor has been associated with being exploited and oppressed. The poor are not merely deprived or destitute; they are also despised and regarded as inferior. In short, the dignity of the poor is threatened and diminished because of the contempt they face from their fellow citizens. ${ }^{21}$ Whybray notes that the voice of the poor themselves is missing from the book of Proverbs and that Proverbs 1-9 contains no direct reference to the poor. ${ }^{22}$

However, there is no way to talk about poverty without talking about hunger as both are deeply intertwined. Poverty causes hunger while hunger leads to a deeper level of poverty especially when disease or crime sets in. Today, economic or material poverty remains a real threat especially in the developing world and societies ravaged by wars, famines and diseases are especially vulnerable to poverty. That poverty is endemic in Africa is common knowledge, and in certain parts of the continent, Jesus' classic dictum, "The poor you will always have with you..." (Matt 26:11) seems to operate in the reverse, "The rich you will always have with you," since the poor constitute the majority. It is even more regrettable that most of the victims of hunger and poverty in Africa (or around the world) are women and children. ${ }^{23}$ Mercy Oduyoye affirms that in Africa, there is 'feminisation of poverty'. ${ }^{24}$ But the African woman tries daily to bear her burden of poverty with as much dignity as she could muster even in extremely dehumanising conditions. She remains hospitable and generous even in the face of excruciating poverty. Given that the bane of the poor is

\footnotetext{
18 Quoted from World Development Report (WDR) 2000-2001. Accessed online 18 September 2012 from: http://siteresources.worldbank.org/INTPOVERTY/Resources/WDR/overview.pdf

19 Boerma (1979:3, 29); Hoppe (2004:15, 17); Wright (2011:255).

20 Whybray (1990:116); cf. Spangenberg (1991:245).

21 See Boerma (1979:19-20); Spangenberg (1991:245-6).

22 Whybray $(1990: 113,114)$.

23 Sixty percent of the world's hungry are women (MDG Report - Goal 5, 2010). Out of the 35 million people living with HIV/Aids, 65 percent of young people living with HIV/Aids are women. while 90 percent of all children and 60 percent of all women living with HIV are in sub-Saharan Africa (UN Aids Report on the Global Epidemic, 2010).

24 Oduyoye (1995:210-11).
} 
hunger, how can a reading of Proverbs 9:1-6 speak to the problem of hunger and poverty in Africa, and what role should women play in the action against Africa's endemic poverty?

\section{A Socio-Economic Reading of Proverbs 9:1-6}

Wisdom has built her house; she has hewn out its seven pillars. She has prepared her meat and mixed her wine; she has also set her table. She has sent out her maids, and she calls from the highest point of the city. "Let all who are simple come in here!" she says to those who lack judgment. "Come, eat my food and drink the wine I have mixed. Leave your simple ways and you will live; walk in the way of understanding. (Proverbs 9:1-6).

The first time we meet Woman Wisdom in the book of Proverbs is out there in the street and in the public place. ${ }^{25}$ But now she no longer roams. She has her own place, built by her own hands. She has become established. As noted earlier, the picture of Woman Wisdom in Proverbs 9:1-6 is one of an influential figure and of a woman of considerable means. Her wealth could be discerned from the fact that she could afford to build a house and from the type of house she built - a mansion. According to Yoder, archaeological evidence from the Persian period shows that the use of multiple columns in a house indicated wealth and status and that Woman Wisdom's house was the type owned by the wealthiest of that period. $^{26}$ Woman Wisdom's ability to afford and host a sumptuous feast was also an indication of her wealth. After all, she not only had a retinue of maidservants at her disposal to run basic errands, but she also had meat and wine on the banquet table, both delicacies that only the rich could afford.

Her influence is demonstrated by the fact that she made her announcement from the highest point in the city - from the highest quarters, from a position of honour and privilege, from the top. Her voice was authoritative; it would command respect. She called. But to whom did she call? Although she undeniably addresses humanity in general in $8: 4,{ }^{27}$ here her guests are narrowed down to the simple and "those who lack..." (9:4). Ordinarily, the wealthy would invite their equally wealthy (or even wealthier) friends to their banquet but there is no indication here that Woman Wisdom was calling out to her rich friends. Her call was to anyone who cared to come and eat - it was to the neighbourhood idiot, the street trader, the street children, the wanderer, the hungry, the poor, and those who lack. Anyone was free to come to the table.

Remarkably, Woman Wisdom had personally taken pains to prepare the meal and to mix the wine for her guests. The question is why would anyone be this indiscriminately charitable? Could she have thrown out this open invitation out of compassion? Or was it because she simply wanted to show off wealth? However, one thing is clear - Woman Wisdom had more than enough and she was ready to share her abundance with "those who lack". More importantly, it appeared this woman recognised the wisdom in sharing. An African aphorism says, "One rich man in the midst of six poor men is a poor man". In other words, that rich man's wealth is uncertain because of the demands and the real threat from his kin.

But Woman Wisdom pointed out that beyond the eating and drinking, beyond the sharing and caring, and beyond the camaraderie they would share in her cosy mansion, there was life on offer. She was offering a quality life that was born out of wisdom. It

\footnotetext{
25 Proverbs 1:20-21 - Wisdom calls aloud in the street, she raises her voice in the public squares; at the head of the noisy streets she cries out, in the gateways of the city she makes her speech.

26 Yoder (2001:100).

27 Whybray (1990:103).
} 
seems this woman was simply reiterating earlier statements in the unit of Proverbs 1-9 that wisdom possessed life $(3: 16,18 ; 8: 35){ }^{28}$ The life that Woman Wisdom offered was a good life, for it promised with it riches and honour as well as lasting wealth and prosperity (Prov $8: 18-21 .^{29}$

The striking resemblance between Woman Wisdom and the אשֶת חַיל 31:1031 readily comes to the fore here. The אשׁת חַיל is undoubtedly also a woman of substance and of some standing in society. Whybray remarks that, "The social and economic status of this lady is clearly high..." 30 She was a wise woman who had acquired wealth by dint of wisdom and diligence. Again, like that of Woman Wisdom, the hospitable spirit of the is equally glaring as she gives of her substance to the poor and the needy (Prov $31: 20){ }^{31}$

\section{Being Wise and Being Female in Africa - Woman Wisdom's Call}

Spangenberg has rightly noted that “... poverty cannot be combated by only one or two isolated agencies. In modern society, the fight against poverty requires a team effort. On the other hand we should be realistic and face the fact that poverty can never be wiped out completely" ${ }^{32}$ If poverty cannot be eradicated in Africa, surely, it can be alleviated. At any rate, Africa's socio-economic realities today demand radical intervention. The argument in this paper is that the interpretation of Woman Wisdom's call and action in Proverbs 9:1-6 offers certain strategies that could help in combating the scourge of poverty on the continent. Of course, the dynamics for working these out would need to be determined by concerned agencies to fit their specific contexts.

First, any lasting solution to the problem of poverty demands that the rich be ready to share with the poor of their abundance and overflow. This ought to be done in a spirit of liberality and not in a condescending or grudging manner. Current winner-takes-all economic formulas in which the rich are the winners and the poor the losers will simply not work on the long run. Woman Wisdom could be seen as an imagery of the affluent, an open-handed affluent woman but the point behind her largesse should not be misconstrued. Woman Wisdom clearly demonstrates that it is sheer wisdom to feed the hungry and the poor and the call to her banquet is not just an invitation to eat and drink or to 'wine-tasting,' it is an invitation to drink from her fountain of wisdom and of life. It is an invitation to sustainable livelihood and prosperity. This woman's wisdom shines through in her willingness to empower others to succeed.

Second, a situation in which millions of African children go to bed hungry every night is indefensible. Mother Africa should arise and feed her own children. There is clearly a dearth of wisdom in an environment where poverty is king and wealth is concentrated in the hands of a few who are reluctant to share. Africa has enough resources to take care of her own and a holistic dialogue on wisdom must take into account Wisdom's ability to

28 Proverbs 3:16 - Long life is in her right hand; in her left hand are riches and honor.

Proverbs 3:18 - She is a tree of life to those who embrace her; those who lay hold of her will be blessed.

Proverbs 8:35 - For whoever finds me finds life and receives favor from the LORD.

29 Proverbs 8:18-21 - With me are riches and honor, enduring wealth and prosperity. My fruit is better than fine gold; what I yield surpasses choice silver. I walk in the way of righteousness, along the paths of justice, bestowing wealth on those who love me and making their treasuries full.

31 Proverbs 31:20 - She opens her arms to the poor and extends her hands to the needy.

32 Spangenberg (1991:246). 
minister to the poor. Such a dialogue should call for an equitable distribution of resources so that those we regard as a public menace on our streets and in our marketplaces could also have a place at the table in the mansion with perfect pillars.

Lastly [and I may step on some masculine toes here], the close of the last and the onset of the new century have shown that modern economic ideologies are losing ground, globally. While communism is in the early stages of rigor mortis, capitalism seems to be intermittently on life support in several countries over the last few years - what with the proliferation of bank bailouts in Europe, America and other parts of the world. Without a doubt, when it comes to today's global economics, conventional wisdom, which is essentially the wisdom of 'wise men,' is fast failing. Woman Wisdom's portrait in Proverbs 9:1-6 could be regarded as a call to women and women groups in Africa to put heads together to tackle the problem of hunger and poverty in their domain. The same acumen and principles that they have employed successfully in home management from generation to generation could be tapped into today even in the face of scant resources. Being wise and being female in Africa entails responding positively and urgently to Woman Wisdom's call!

\section{BIBLIOGRAPHY}

Baumann, Gerlinde 1998. “A Figure with Many Facets: The Literary and Theological Functions of Personified Wisdom in Proverbs 1-9", in Athalya Brenner and Carole Fontaine (eds.). Wisdom and Psalms. The Feminist Companion to the Bible (Second Series 2). Sheffield: Sheffield Academic Press. 44-78.

Boerma, Conrad 1979. Rich Man, Poor Man - and the Bible. Translated by John Bowden from Dutch. London: SCM.

Brenner, Athalya 1993. “A Mother's Instruction to Son and to Daughter”, in Athalya Brenner and Fokkelien van Dyk-Hemmes (eds.). On Gendering Texts: Male and Female Voices in the Hebrew Bible. Leiden: Brill. 127-130.

Camp, Claudia V 1985. Wisdom and the Feminine in the Book of Proverbs. Sheffield: Almond.

Claassens, L Juliana M 2004. The God Who Provides: Biblical Images of Divine Nourishment. Nashville: Abingdon.

Clements, Ronald E 1992. Wisdom in Theology (The Didsdury Lectures).

Grand Rapids: Eerdmans.

Clifford, Richard J 1999. Proverbs: A Commentary (OTL). Louisville:

Westminster John Knox.

Crenshaw, James L 1998. Old Testament Wisdom - An Introduction.

Louisville: Westminster John Knox.

Dell, Katharine J 2006. The Book of Proverbs in Social and Theological Context.

New York: Cambridge University Press.

Dell, Katharine J 2009. "Proverbs 1-9: Issues of Social and Theological Context". Interpretation 63/3:229-240.

Harris, Scott L 1995. Proverbs 1-9: A Study of Inner Biblical Interpretation (SBL 150). Atlanta: Scholars Press.

Hoppe Leslie J 2004. There Shall Be No Poor among You: Poverty in the Bible. Nashville: Abingdon. 
Lang, Bernhard 1986. Wisdom and the Book of Proverbs: An Israelite Goddess Redefined.

New York: The Pilgrim Press.

Masenya (ngwana' Mphahlele), Madipoane J 2004. How Worthy is the

Woman of Worth? Rereading Proverbs 31-10-31 in African-South Africa. Peter

Lang: New York.

McKinlay, Judith E 1996. Gendering Wisdom the Host: Biblical Invitations to

Eat and Drink (JSOTSup 216). Sheffield: Sheffield Academic Press.

Meinhold, A 1991. Die Sprüche 1: Sprüche Kapital 1-15 (Zürcher Kommentare AT, 16.1). Zürich: Theologischer Verlag.

Murphy, Roland E 1990. The Tree of Life: An Exploration of Biblical Wisdom Literature (Anchor Bible Reference Library). New York: Doubleday.

Murphy, Ronald E 1995. "The Personification of Wisdom”, in John Day, Robert P Gordon and H G M Williamson (eds.). Wisdom in Ancient Israel: Essays in Honour of JA Emerton. New York: CUP. 222-233.

Oduyoye, Mercy Amba 1995. Daughters of Anowa: African Women and Patriarchy. Maryknoll: Orbis.

Perdue, Leo G 1997. "Wisdom Theology and Social History”, in Michael L Barré, (ed.). Wisdom You Are My Sister: Studies in Honor of Ronald E Murphy, O Carm on the Occasion of His Eightieth Birthday (CBQ Monograph Series 29).

Washington, DC: The Catholic Biblical Association of America. 78-101.

Schroer, Silvia 1995. "Wise and Counselling Women in Ancient Israel: Literary and Historical Ideals of the Personified okmâ", in Athalya Brenner (ed.). A Feminist Companion to Wisdom Literature (The Feminist Companion to the Bible 9).

Sheffield: Sheffield Academic Press. 67-84.

Shupak, Nili 1993. Where can Wisdom be Found? The Sage's Language in the Bible and in Ancient Egyptian Literature (OBOS 130). Freiburg: Universität Verlag.

Sinnott, Alice M 2005. The Personification of Wisdom (SOTSS). Hants: Ashgate.

Spangenberg, Izak 1991. "The Poor Will Always Be with You”. Wealth and Poverty in a Wisdom Perspective. In HL Bosman, IGP Gous and IJJ Spangenberg (eds.).

Plutocrats and Paupers: Wealth and Poverty in the Old Testament. Pretoria: JL van Schaik. 228-246.

Waltke, Bruce K 2004. The Book of Proverbs: Chapters 1-15. Grand Rapids: Eerdmans.

Weeks, Stuart D E 1994. Early Israelite Wisdom. Oxford: Clarendon.

Whybray, RN 1990. Wealth and Poverty in the Book of Proverbs. JSOTSS 99. Sheffield: Sheffield Academic Press.

Whybray, Roger N 1995. The Book of Proverbs: A Survey of Modern Study. Leiden: Brill.

World Development Report 2000-2001. Accessed 18 September 2012 online from: http://siteresources.worldbank.org/INTPOVERTY/Resources/WDR/overview.pdf.

Wright, CJH 2011. "The Righteous Rich in the Old Testament". Evangelical Review of Theology 35(2):255-264.

Yoder, Christine Roy 2001. Wisdom as a Woman of Substance: A Socioeconomic Reading of Proverbs 1-9 and 31:10-31 (BZAW 304). Berlin/New York: Walter de Gruyter.

Yoder, Christine Roy 2003. "The Woman of Substance (אשת היל): A Socioeconomic Reading of Proverbs 31:10-31”. JBL 122/3:427-447.

Yoder, Christine Roy 2009. Proverbs (AOTC). Nashville: Abingdon. 